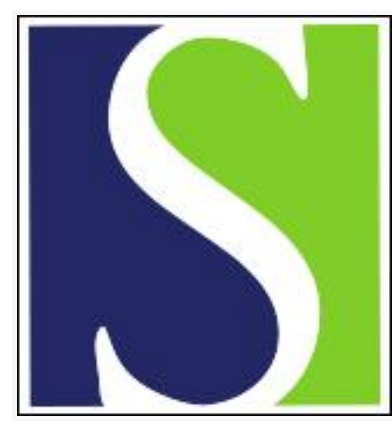

Scand J Work Environ Health 1999;25(6):597-604

https://doi.org/10.5271/sjweh.486

Issue date: Dec 1999

\title{
Influence of worklife on public health
}

by Aronsson G

The following article refers to this text: 2001;27(6):365-372

Key terms: contingent work; control; differentials; flexibility; labor-market change; polarization; stressor; work environment

This article in PubMed: www.ncbi.nlm.nih.gov/pubmed/10884159

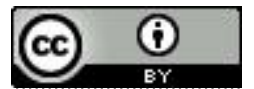




\title{
Influence of worklife on public health
}

\author{
by Gunnar Aronsson, PhD
}

\begin{abstract}
Aronsson G. Influence of worklife on public health. Scand J Work Environ Health 1999;25 (6, special issue):597-604.

The paper discusses worklife changes with broad public health impacts. Central concepts for the analysis of the labor market are flexibility and differentiation. One conclusion is that there is ongoing polarization and differentiation - with an increased group of people in time-restricted (contingent) employment and self-employment and a reduced group of core workers. Greater demands for adaptability are being imposed on the majority of employees. Concepts related to flexibility and differentiation at an individual level are adaptability, identity formation, loss of control, trust and lack of trust, allostatic load, long-term strain, and psychological contracting. The labor market and organizational changes are discussed in relation to what can be called "institutional effectiveness". These changes refer to how institutions commissioned to act for the prevention of injuries and to contribute to worklife quality handle the new conditions. Finally, work-environment research is discussed in relation to a new and more complex pattern of exposures and interactions. One conclusion drawn is that it is becoming increasingly difficult to identify workplaces at risk.
\end{abstract}

Key terms contingent work, control, differentials, flexibility, labor-market changes, polarization, stressors, work environment.

In any discussion of worklife's importance for future public health and public health investments, it is important to take up at least some of the following questions: Where will jobs be available and under what conditions will work be performed? Are there tendencies in the transformation processes of worklife that suggest a movement towards polarization and inequality in relation to health? Can new stressors be identified? How well equipped and efficient are current regulation systems in handling ongoing changes in worklife? To approach answers to these questions, links must be made to the driving forces in worklife development, such as economic growth and structural transformation, technology development, and social and political change. The discussion is exemplified primarily on the basis of conditions in Sweden, but many of the questions posed can be expected to recur in any highly industrialized welfare state with a heavily internationalized economy.

Included among the framework conditions of health is general economic development. A high level of economic growth appears to have a more favorable effect on work conditions and the job environment than low growth. This assumption applies particularly to physical job stress, hiring conditions, and opportunities for decision making on the job. However, high economic growth can also lead to increased time constraints and greater psychological demands at work, which, in turn, may result in further tension between work and family roles. High demand for workers puts employees in a stronger negotiating position with respect to a number of matters directly or indirectly associated with health. High rates of economic growth make it easier to maintain society's systems of economic, social, and medical security. Cutbacks in the social security system would probably be felt the most strongly by low-wage earners (ie, blue-collar workers, particularly women) (1).

\section{Differentiation and flexibility of the labor market}

The trend in worklife in many countries can be described in terms of organizations being exposed to centrifugal forces that generate differentials in the labor force and in employing organizations according to a center-periphery structure (figure 1) (2). It can also be described as a process whereby a strong center induces uncertainty in peripheral structures so as to create stability and security at the core. The bearers of uncertainty are principally subcontracting companies and their employees and

Swedish National Institute for Working Life, Solna, Sweden.

Reprint requests to: Professor Gunnar Aronsson, Swedish National Institute for Working Life, S-171 84 Solna, Sweden. [Email: gunnar.aronsson@niwl.se] 


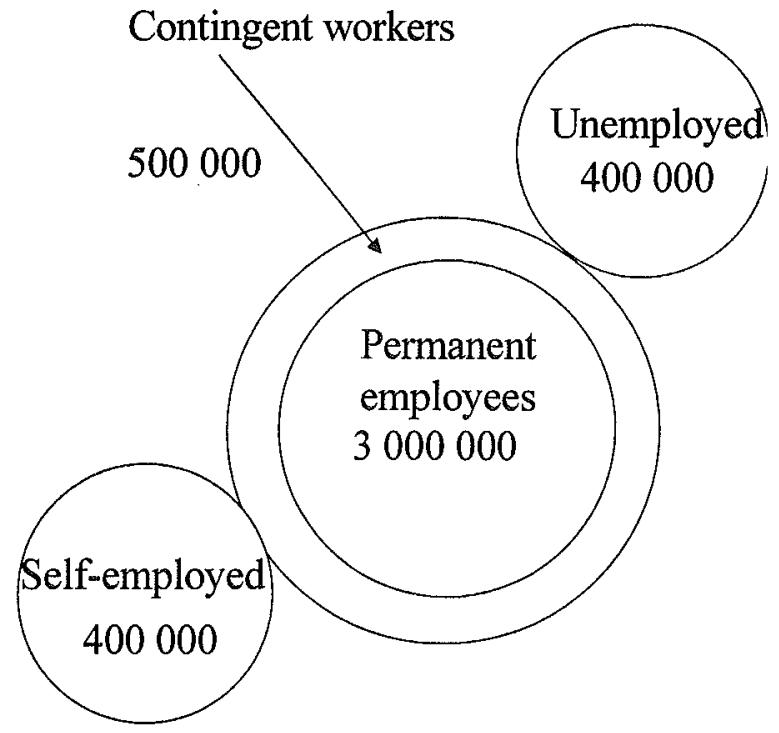

Figure 1. Labor-market differentiation.

people on time-restricted employment contracts. That the labor market and labor force is becoming increasingly differentiated will come to be of significance from a public-health perspective.

The ideal steering the trend towards this new structure is the slimmed-down organization focusing on core operations. With this model, flexibility is to be achieved through variation in the number of employees, workhours, and skills and through the procurement of special services, subcontractors, and so on. At the core, there are, at least so far, principally employees with relatively good job security and opportunities for development with regard to personal skills and also job content and pay.

In many respects the ideal of healthy work, in which demands and control are balanced in combination with development opportunities and learning (3), is a reality for this core group, which is a major plus from the perspective of health. But, in Sweden, it is also the case that the pace of work has increased, and the country now occupies top position within Europe in this respect (4).

Internal authoritarian structures in Sweden seem to have been dismantled to a greater extent than in most countries of the European Union (4). At the same time, comparisons seem to suggest that customer direction and control is beginning to supersede in-house control. In such a shift in direction and control there is a potential for learning, but there is also a risk that the needs of people in low positions in "technified" service occupations, facing heavy time pressure, are subordinated to the wishes of customers (moreover, of customers who only see their own interests and lack understanding of employees' work environments and work conditions). There is talk in this context of a modern form of servitude (1).
The core is encircled by a band of people in various kinds of time-restricted employment, whose task it is to assure the organization's flexibility in relation to the troughs and peaks of production. Currently, they make up around $15 \%$ of the labor force. Work conditions in and motives for time-restricted employment vary considerably. There are considerable internal differences within this band, with recent major numeric increases in the categories of persons employed to meet emergency requirements and persons working on projects. These 2 categories of employment are linked to understaffing and modern goal-oriented forms of work, respectively. Women comprise a large majority in the former category, and men the latter. It is also primarily among employees hired to meet emergency requirements that the effects of work conditions and insecurity are manifested in the form of an increased risk of ill health [Unpublished manuscript: Aronsson G, Gustafsson K, Dallner D. Tidsbegränsad anställning; arbetsvillkor, arbetsmiljö och hälsa (Health and work conditions in contingent work)].

A further circle consists of the self-employed. There are around 400000 self-employed people in Sweden, and the shift from goods to service production is a driving force in the growth of this group. Service production suits self-employment better than goods production, and many services can be efficiently produced in companies of this kind. Very little is known about the health situation in these groups. It is likely that conditions vary considerably according to the forces underlying self-employment and the motives for it. Most at risk are probably the people who have lost their jobs, but who continue on their own in the same industry, competing primarily by means of long workhours and low costs. Approximately a quarter of new enterprises formed in Sweden in 1994 were generated by unemployment or the risk of unemployment (5).

A 4th segment consists of the unemployed and of people on various government-sponsored job-training or assisted-employment schemes. A future risk seems to be that an ever larger group of this kind is being established; its members are jobless and they live under very restrictive personal-financial circumstances for a long period of time, with negative health outcomes as a consequence. The changed labor market is the driving force in bringing the concept of "economic stress" to the fore (6). But there are likely to be behavioral consequences, as well as the direct negative health impacts of economic stress, in that people under financial pressure are prepared, to a greater extent, to take risks at work and to ignore safety prescriptions and rules.

Training and education interact with differentiation in the labor market. Access to skills development in a person's own work and the presence of a system of what is called "life-long learning" are not only paths to healthier work in the person's current workplace, they also 
strengthen his or her general worklife position. If corporate in-house skill development increases in importance, there is a risk of even more intense polarization between the core group and "just-in-time" employees and the unemployed.

High unemployment reduces the opportunities of people still in employment to choose with regard to both work tasks and job form. One consequence may be that people stay too long with tasks and in jobs that they really should leave on health grounds. People who are "locked-in" in this way show a high frequency of symptoms of ill health (7). During a period of high unemployment in Sweden, as high as $25 \%$ of permanent employees could be categorized as locked-in. Healthy personnel turnover, which provides a person with a new and more appropriate work environment, has diminished, as too has the force of personnel turnover as a means of exerting pressure to promote a better work environment.

Increased customer dependence hinders the utilization of centralized workhour solutions, since demand varies between economic sectors. There is an ongoing process towards workhours being determined at the local and individual level. A trend, which applies above all in industry, is for workhours to be demand-governed (ie, for production to be controlled by customer order). Overtime is being replaced in part by a system of plus and minus time as a method for dealing with fluctuations in demand. There have still been no medically or socially oriented evaluations of this shift in patterns of workhours. A cautious guess is that the growing plusminus system, which entails variation over the year but in principle reduces overall hours worked, will be positive from a health perspective in comparison with conventional overtime work, but only provided that the worker can influence his or her workhours and that changes are announced in good time.

Another trend, principally among white-collar groups, is towards the working of a large quantity of unpaid overtime (8) or towards the conclusion of individual employment contracts in which the right to overtime compensation is forfeited in exchange of, for example, an additional week's vacation. From a trade-union perspective it is feared that this trend will result in a substantial increase in the number of hours actually worked, and - if indeed this becomes the case - there are grounds for misgivings in terms of workers' health. The relationship between lengthy workhours or overtime and ill health has not been studied much in Sweden or abroad, but - in a new Japanese study - it is stated that a couple of hours of daily overtime is associated with a clear excess risk of heart infarction (9). The disposition to work overtime is also increasing as a consequence of more severe financial insecurity, lower levels of pay, and misgivings over the future sustainability of the public social-insurance system.
The long-term trend in workhours is for ever more people to work constantly or periodically outside the time interval (over the 24 hours of the day) when body and mind are functioning optimally from a performance perspective (10). For many, the extra effort that is required during shift work and under various work-scheduling arrangements elicits a price in terms of health in the longer term. New research findings suggest ever more clearly that there is a relationship between exhaustion or stress and the capacity of the immune defense system to combat infection $(11,12)$. In this respect, there is potential for health-promoting efforts to be made with regard to the knowledge level of organizations and private individuals.

\section{Structural transformation and technical and organizational change within goods production}

More and more of the production of goods is now taking place within multinational corporations or in networks of subcontractors that are linked to such corportations. Reduced trade barriers and free capital movement enable production ever more easily to be moved between countries. Large companies in mature industries are likely to act increasingly as agents of structural transformation - through shifts in production location, plant closures, and the partitioning or purchasing of industrial operations. A single currency in the European Union will accelerate the number of corporate mergers. For employees, this process may entail increased uncertainty, and it may impose greater demands on a person's ability to handle production switches and job insecurity.

\section{Extraction, manufacturing and recycling}

From a work-environment perspective it is of interest to distinguish between operations in which people at work are directly involved in the handling of physical objects and in which they are not. By means of technology, it is possible to reduce certain kinds of risks related to proximity to and the handling of physical objects at the rawmaterials extraction stage. Through automation and information technology workers can be distanced physically from the object of work, with industrial robots and other tools taking over direct contact with the objects in question. In the long run, this process should entail a substantially reduced risk of occupational injury in the course of regular operations, But hazards still arise, primarily during the transformation of production systems and intervention in cases of disturbances in production. In remedying a disturbance, the employee is again in close contact with the object of his or her work and the machines involved, and he or she faces risks 
accordingly. Work of this kind is often performed under stress and time pressure. Disturbances and breakdowns will also become ever more expensive in the future with increasingly capital-intensive production.

Occupational accidents and diseases in the manufacturing industry have decreased in number and severity for many years in Sweden, they but still account for substantially high proportions of ill-health outcomes and exclusions from the labor market. A continued decline in these proportions can be expected given that the number of people in direct contact with things and processes is decreasing.

Even though technology has permitted a reduction in the direct human handling of objects at the extraction and manufacturing stages, the picture is not as unequivocal in the transportation and goods distribution arena. Goods handling is constantly on the increase, and many companies are attempting to minimize inventories and warehousing costs. High utilization of transport-vehicle capacity is an important and weighty element in profitability. Demands for precise deliveries are growing. It is probably in these kinds of operations that it is the most difficult to have an impact on occupational accidents and diseases by means of technological improvement. Problems in the wholesale and retail trades and, to some extent, also in hotels and restaurants, are more related to inappropriate building design, and - in the longer term - can only be ameliorated through the application of work-environment expertise during refurbishment or construction.

At the final recycling stage there is likely to be a number of unanticipated work-environment hazards. Recycling plants will probably have the potential for a broad spectrum of environmental hazards, such as noise and risk of overexertion, and there are also bacterial problems related to waste management. Recycling requirements affect the entire production process, but environmental research and processes focusing on materials and assembly so as to render the dismantling process workenvironment friendly seem to be in their infancy.

Much of the rationalization work performed by companies so far seems to have focused on goods production. But, as the value of goods comes more and more to depend on their service content, investments in rationalization will, to a greater extent, be oriented towards service work. Despite the changed focus of rationalization, the long-term trend is for ever fewer people to work directly in traditional industrial settings and for more to work in office, service and care environments.

\section{Care and welfare and the school}

The care and welfare and education sectors largely comprise "human service organizations", ones that have a great influence on the terms upon which people live. Accordingly, they are particularly interesting from a public-health perspective. How care or welfare institutions and schools operate is important not only for their employees, but also for their patients, clients, or pupils. It is also of significance for the hundreds of thousands of persons in paid employment whose close kin spend all or parts of their time in institutions in these sectors.

Within the care and welfare sector, in Sweden as in many other countries during the 1990 s, politically initiated rationalization and savings programs have been in operation. Among other things, these have concerned changes in control systems, and both corporatization and privatization. The aims are many and varied, but one is to achieve cost reductions via personnel cutbacks. At the same time, it is hard to believe that employment can be reduced more than marginally in the care and welfare sector. New technology can lead to the substantial shortening of hospital waiting times, but it may also generate new needs for care and increase demand for caring intervention. Changes in the age structure of the populations in many countries also point to an increased need for care of the elderly. In the fields of care for children and the elderly, the potential for rationalization and personnel cutbacks is restricted. Naturally, there are human and cultural blockages in the way of applying electronic surveillance and robotics.

Many employees in the health and welfare sector in Sweden seem to share the experience of increased work load (13). In addition, as stress and work-environment problems are intrinsically linked to major changes, there is still a striking purely physical work load. There are no technical changes on the way that might eliminate heavy lifting or aid the moving of patients.

From the perspective of gender and ill health, changes in the health and welfare sector are of special interest, in particular because such changes are being effected in a strongly gender-segregated sector. Transformation of public-sector operations affects a large number of women, and not just as employees. Cutbacks may mean that paid caring work performed by women is translated into unpaid caring work performed by exactly the same women. Accordingly, any reduction in the investment in public care for women and children may impose even greater pressure on women in paid employment.

Compulsory schools and high schools form a giant workplace, encompassing around 1.5 million people in Sweden. School pupils in Sweden are also covered by the provisions of the country's work-environment legislation. Demands for savings, education-voucher schemes, and increased outsourcing have led to major organizational changes in particular schools. The teaching profession is being allocated greater authority and responsibility for school operations, with regard to both finance and educational approach. Computers, multimedia, and 
the Internet have made a definitive entrance to schools, and the consequences are likely to be far-reaching for both the instructional situation and school organization.

General statistical surveys have shown teachers to be a highly pressurized group from a health perspective (14). Like care and welfare personnel, teachers constitute an occupational group with a high propensity to work while sick (14, unpublished report: Aronsson G, Gustafsson K, Dallner M. Sick but yet at work: an empirical study of sickness presenteeism). Many of the work-environment problems to be found inside schools are of a kind that they cannot be captured in occupational injury statistics before they are well developed. They concern issues of collaboration, contentment and pleasure at work, reorganization, and human relations. Psychological and social issues are growing in importance, and the threat of unemployment and an uncertain future for young people are casting their shadows over motivation and work in schools. That groups of personnel with the tasks of identifying and preventing problems early have been reduced in number and are undersized should therefore be regarded as a disturbing development.

In public-sector operations, it seems harder than in their private counterparts to shrink or expand operations in response to external demand. There is less self-regulation in that public organizations generally lack the expansion option and must principally meet demands for operative transformation through various kinds of cost reduction. Accordingly, savings and personnel cutbacks will correspond poorly to demand, or to politically imposed investment levels and care guarantees. In this context, there is a genuine transformation problem with no simple solution, one that makes it doubtful whether the negative work-environment trend evident in parts of the public-service sector can in fact be broken even if budgets are balanced.

\section{Information technology - the dissolution of temporal and geographic boundaries}

Information technology will continue to have increased significance with regard to the transformation of worklife, albeit partially in other ways than have been previously envisaged. The joint growth of telecommunications, micro electronics, and computers constitutes a powerful force for change. Temporal and geographic limitations to interaction and control are being strikingly reduced through the extension of the net and its increase in capacity. It is not only manufacturing companies that reap benefit from this situation, but also health-care organizations in which information can rapidly be transmitted via telecom links and utilized by experts wherever they happen to be.
Sweden is one of the world's most computer-intensive countries, and the rate of increase in computer users is still high. Therefore work-environment hazards related to computer use will have a very considerable impact from a public-health perspective. One example lies in the "mouse elbow", which new research suggests has become an extensive complaint affecting as many as a million people in Sweden (Unpublished manuscript: WigaeusHjelm, E. Hälsa i datoriserat arbete). Since increasing numbers of work functions and tasks can be handled by computer, there are also fears that many people will be affected by physical "underload".

Integrated information techniques make it possible to locate paid-employment activities in places and times to which they have not conventionally belonged, and these activities have both collective and individual forms. There are operations that require immediate handling "on call". Forecasts suggest that this kind of job is strongly on the rise in many countries. It has been estimated that as many as 100000 persons in Sweden will work in what is referred to as "call centers" within a few years. However, the refinement and rationalization of tasks in this manner can entail the allotment of very few accompanying occupational pursuits, and this situation is hazardous in respect to both an ergonomic perspective and job security.

The trend towards more spatially and temporally independent work raises a series of questions of a workenvironment-related nature (15). Changes of boundaries in time and space in information technology may be supposed to be of great importance for the regulation of work-rest rhythm, the balancing of various life roles, collaboration patterns, and contact networks and learning conditions. They also affect the person's capacity to work independently and structure his or her time. At a general level, it is a matter of the employers' direction and control over work having been liberated from their temporal and spatial setting.

\section{New worklife stressors}

An overall feature of the new worklife that has been constructed is that greater demands for adaptability are imposed on the majority of individual employees. No fully coherent theory related to the demands of new work has yet been developed. However, there are many psychological or psychologically oriented theoretical formulations that can be supposed to have a major potential to capture various sides of the new "flexibilized" worklife. Probably the following conditions and stressors will obtain even greater prominence in the future. 


\section{Change-related stress, identity formation and constant adaptation}

Capacity to adapt, or disposition to change, has come increasingly to be regarded as a particularly valuable personal attribute in societies with a high pace of change. But disposition to change can also stand for one-sided (nonmutual) adaptation, which may mean that the person wipes out a part of his or her identity and self-esteem is threatened (16). To adjust easily to different contexts to gain personal advantage can lead to superficiality and rootlessness. The capacity to preserve a strong identity may be a person's best way of handling uncertainty in a changing environment. Security in one's personal identity provides protection during processes of change. Vulnerability to change is also related to a restricted occupational role and narrow specialization. An occupation that demands the application of large parts of the personality, and develops this application, provides the person with an identity that can be carried through all kinds of transformations.

\section{Loss of control, trust and lack of trust}

In discussions of increased flexibility and the slimmingdown of organizations, insecurity has been a recurring theme. Expressed in terms of occupational psychology, people live under the threat of losing control over their worklife situations - over their employment and personal finances $(7,17)$. Such a threat can be supposed to lead to insecurity, but the human and psychological aspects are likely to touch upon even deeper human needs, namely, those concerned with the existential need for trust. The psychological core to trust is the sense that people and things are reliable. It is through this reliability that the human identity is created and the social world becomes more predictable.

Strongly pursued "flexibilization" of employment conditions may lead to a permanent perception of insecurity, with the risk of what has been called "mistrust ill health" obtaining increasing importance in the future (18). Ill health of this kind can be described as a psychological, emotional, social, and somatic condition, which is related to the boundaries of human capacity to handle uncertainty and risks in the environment.

\section{Psychological contracting}

Theories of psychological contracting have become valuable instruments for analyzing the individual consequences of rapid changes in labor markets and production. (See, for example, reference 19.) In an occupational context, any such contract defines - explicitly or nonexplicitly - the mutual obligations of the employee and employer.

The traditional employment system, which has long been dominant in Sweden, may be said to have entailed the affordance of job security and employment opportunities in exchange for hard work and loyalty. But, with the change in employment conditions resulting from downsizing and the application of the principles of flexibility, the old contract is being rescinded. Resulting perceptions of breach of contract may mean that basic trust is replaced by basic mistrust, reduced belief in the future, and diminished work motivation. This possibility can be expected to apply especially in the public sector, which, in Sweden as in many other countries, has historically been characterized by a very stable contract.

\section{Long-term strain and allostatic load}

In modern, slimmed-down, customer-oriented, and inventory-free production, personnel assume - to an ever greater degree - responsibility for flexibility by varying their time input (ie, by adopting the role of buffer). There is a risk that such buffer requirements will have an impact on the degree of opportunity for winding-down and recuperation, a condition that may represent a key dividing line as to whether or not stress will have harmful consequences. In modern so-called allostatic loadand-stress theory, several theoretical concepts and hypotheses for empirical testing have been formulated. The focus of the theory is on the organism's capacity to attain stability through change. Rapid activation of the body's "alarm system" in response to an increased stress load and a quick return to the psychological and physical base level following energy mobilization mean the economic utilization of physical resources. If a person, following a period of strain, cannot return to his or her base level prior to the next period of strain, the strain accumulates with consequences in terms of the overall "wearing-out" of the biological system. A number of conditions can generate excessive allostatic load, accompanied by ill-health outcomes (12):

- normal responses to stress but so frequent that they have an impact on health,

inability to wind down following the experience of strain,

lack of a suitable action repertoire with which to respond to environmental demands,

anticipation, for example, concern, anxiety, mental preparation, when confronted with a demanding or threatening situation. 


\section{Social support and social network}

Another issue is how the flexibilization and just-in-time models, as they are applied to the labor force, may have an impact on social support and social networks. Will the result be a weaker link to supportive networks and result in reduced protection against strain and ill health? Does flexibilization entail a more competition-oriented environment, within which social support is weakened?

\section{Institutional effectiveness}

In any analysis of the significance of work environments and work conditions for the trend in health, account should be taken of what might be called "institutional effectiveness". This concept refers to how institutions with the tasks of acting for the prevention of injuries and contributing to worklife quality function and also to how they handle new conditions in worklife. In this setting, institutional effectiveness is concerned, among other things, with the generation of and opportunities for the implementation of knowledge on new work conditions. It is also concerned with the current state of knowledge and expertise among decision makers and others active in the arenas of safety and organization development.

To the new conditions belong restructuring and differentiation within the core and the periphery of the labor force. The number of operations and people lying, in either a formal or informal sense, beyond the confines of the current social-insurance system and work environment or workhour stipulations is on the increase. Occupational health care and work-environment investments and legislation have by tradition focused on the core of permanent employees (who are gathered in relatively stable and geographically fixed positions). The new structures are far more variegated and therefore confront work-environment institutions with new demands and challenges. There is a risk that the trend towards looser contractual forms of work will not be matched by adequate institutional changes (20).

Rehabilitation is of key importance from a publichealth perspective, and it is also supported in Sweden by extensive legislation. In this context, one question that can be posed concerns the prerequisites for finding rehabilitation places in slimmed-down organizations with an explicit concentration on high-performing personnel in core operations with few side-tasks and surrounding activities.

Many of the new work-environment issues are closely associated with aspects of production. That staffing level has stress and health impact is clearly apparent. Is understaffing therefore a matter for the labor inspectorate? This question is likely to be posed ever more often in the future. For major occupational groups, worklife is now characterized by one personnel-cutback process after another. Existing institutions are poorly equipped with regard to the methods, knowledge, and expertise required to prevent the dysfunctioning that is often apparent in this setting.

\section{Changed prerequisites for research}

In any overall assessment of the health trend it is important - in so far as is possible — to take account of both complexity and dynamics (eg, that deterioration in one field is compensated by improvement in another). The emerging picture is that people in the worklife of the future will have greater mobility in a variety of respects. Such mobility is partly personally chosen and partly enforced. On its various dimensions, it concerns movement between employment and unemployment, between fulltime and part-time work, between occupations, between study and paid work, and between job tasks with different degrees of load and different personal-development opportunities. To the picture also belong work-transformation stresses, insecure terms of employment, telework and work at home, and the fact that the boundary between industrial and office work is becoming ever less clearly demarcated. Fear of unemployment or insecure employment may dampen work-environment criticism, and therefore current signal systems for occupational hazards will not operate as they did previously. It is becoming increasingly difficult to identify workplaces at risk.

In addition, the exposure picture is becoming complex, given interaction between various health-promoting and health-impairing factors of different kinds in diverse environments and at divergent points in time. The consequence is likely to be an increase in nonspecific complaints. It is already apparent that changes in this direction affect the preconditions under which health and safety work and worklife research is conducted.

\section{References}

1. Salomon R, Grimsmo A. Arbeidsliv mot år 2010 [Working life 2010]. Oslo: Arbeidsforskningsinstituttet, 1994.

2. Aronsson G, Sjögren A. Samhällsomvandling och arbetsliv: omvärldsanalys inför 2000-talet: fakta från Arbetsmiljöinstitutet, 1994 [Societal transition and working life: analysis of contemporary circumstances approaching the 21st century: facts from Sweden's National Institute of Occupational Health]. Solna (Sweden): Arbetsmiljöinstitutet, 1994

3. Karasek R, Theorell 'T. Healthy work: stress, productivity, and the reconstruction of working life. New York (NY): Basic Books, 1990.

4. The European Foundation for Improvement of Living and 
Working Conditions. Second European survey on working conditions. Dublin: The European Foundation for Improvement of Living and Working Conditions, 1996.

5. SOU: hälften vore nog - om kvinnor och män på 90-talets arbetsmarknad, utredningen om kvinnors arbetsmarknad [Half would be enough — on the labour market for women and man in the 90s]. Stockholm: 1996:56. In Swedish.

6. Starrin B, Rantakeisu U, Hagquist C. In the wake of recession - economic hardship, shame and social disintegration. Scand J Work Environ Health 1997:23 suppl 4:47-54.

7. Aronssson G, Göransson S. Permanent employment but not in a preferred occupation. J Occup Health Psychol 1999;2:152 63.

8. Aronsson G. Paid by time, but judged by results. Int J Employment Stud 1999;1:1-15.

9. Sokejima S, Kagamimori S. Working hours as a risk factor for acute myocardial infarction in Japan: a case-control study. BMJ 1998;19;775-80.

10. Åkerstedt T. Vaken på udda arbetstider: om skiftarbete, tidszoner och nattsudd [Awake on odd hours]. Stockholm: Arbetsmiljöfonden, 1995.

11. Cohen S, Tyrell D, Smith A. Psychological stress and susceptibility to the common cold. N Engl J Med 1991;9:606-12.

12. McEwen B. Protective and damaging effects of stress mediators. N Engl J Med 1998;3:171—9.

13. Arbetarskyddsstyrelsen and Statistiska Centralbyrån. Negativ stress $\mathrm{i}$ arbetet - de mest utsatta yrkena: information om utbildning och arbetsmarknad [Negative stress at work - the occupations most at risk]. Solna: Arbetarskyddsstyrelsen and Statistiska Centralbyrån, 1997:1.

14. Aronsson G. Svensson L. Nedvarvning, återhämtning och hälsa bland lärare i grund- och gymnasieskolan [Unwinding, recuperation and health among school teachers]. Solna (Sweden): Arbetslivsinstitutet, 1997. Arbete och hälsa 21.

15. Allvin M, Aronsson G, Hagström T, Johansson G, Lundberg U, Skärstrand E. Gränslöst arbete eller arbetes nya gränser: delstudie 1 [Work without boundaries]. Solna (Sweden): Arbetslivsinstitutet, 1998. Arbete och hälsa 21.

16. Frankenhaeuser M. Arbetets värde och mening - en betraktelse grundad på kunskap om människors behov, förutsättningar och begränsningar [The meaning and value of work]. In Trygghetsrådet-SAF-ptk. Framtidsjobben. Stockholm: Trygghetsrådet-SAF-ptk, 1990:63 - 78.

17. Aronsson G. Contingent workers and health and safety at work. Work Empl Soc 1999:3:439—59.

18. Borgenhammar E. Att vårda liv — organisation, etik, kvalitet [Take care of life]. 2nd ed. Stockholm: Studieförbundet förlag, 1994.

19. Rousseau D M, Wade-Benzoni K A. Changing individualorganization attachments: a two way street. In: Howard A, editor. The changing nature of work. San Francisco (CA): Jossey-Bass Publishers, 1995:290-322.

20. Mayhew C, Quinlan M, Bennet $L$. The effect of subcontracting/outsourcing on occupational health and safety. Sidney: UNSW, 1996. UNSW studies in Australian industrial relations, no 38 . 